І. М. Лоза, В. В. Бригадиренко

Дніпропетровський державний аграрний університет Дніпропетровський наиіональний університет

\title{
РОЛЬ ОСИКОВО-БЕРЕЗОВИХ КОЛКІВ У ЗБЕРЕЖЕННІ РІЗНОМАНІТТЯ ІРУНТІВ І БЕЗХРЕБЕТНИХ ТВАРИН СТЕПОВОЇ ЗОНИ УКРАЇНИ
}

\begin{abstract}
Наведено приклад комплексного підходу до досліджень екологічних особливостей існування острівних лісів (колків) у степовій зоні України. Охарактеризовано основні шляхи грунтоутворення, видовий склад флори. Проаналізовано особливості формування герпетобію пісків у мезогігрофільних і гігрофільних умовах другої тераси долини ріки Самари.

The example of complex approach to research of ecological peculiarities of island forests in the steppe zone of Ukraine is presented. Main ways of pedogenesis, plant species composition and forming of the litter invertebrate complex in mesohygrophilous and hygrophilous sandy biogeocenoses of the second terrace of Samara river valley are characterized.
\end{abstract}

\section{Ветуп}

Біорізноманіття в Україні постійно зменшується через інтенсивне землеробство та господарську діяльність. Стабільність природних екосистем постійно падає. До 92 \% деяких груп земель розорані. Відносне збереження природного різноманіття спостерігається переважно у регіонах, землі яких непридатні для сільськогосподарського виробництва. Тому необхідно напрацювати комплекс специфічних заходів, які дозволять оцінити природне різноманіття на різних рівнях, управляти його змінами.

В умовах степової зони особливої уваги потребує дослідження потенційної лісопридатності територій, що не можуть бути повноцінно використані для створення сільськогосподарської продукції. Дана робота присвячена дослідженню природних лісів піщаної тераси ріки Самара. Знання особливостей умов їх функціонування дозволить використовувати ці специфічні природні біогеоценози для рекультивації антропогенно порушених земель. Мета роботи - дослідити особливості лісорослинних умов арени ріки Самара, надати характеристику грунтів, домінантних видів рослин і безхребетних тварин-герпетобіонтів.

\section{Матеріал і методи досліджень}

Геоботанічні дослідження, визначення видів рослин проводили за загальноприйнятими методиками [10]. Увагу зосереджено на грунтах зі збільшеним зволоженням у весняно-літній період (улоговини піщаної тераси). Для геоботанічних досліджень взято колки, що відносяться до свіжого та сирого типів місцезростань [4; 5]. Вивчення фауни безхребетних тварин проводили протягом сезону 2002 року у чотирьох осиковоберезових колках арени р. Самара з використанням пасток Барбера [1]. Видовий склад доповнений ручним збором безхребетних під рослинними залишками та поблизу води.

\section{Результати та їх обговорення}

Бідність мінеральними колоїдами обумовлює рухливість пісків під впливом вітру. Утворюється еоловоий рельєф, коли дюни чергуються з улоговинами. У таких улоговинах, як правило, овальної форми, формуються біогеоценози особливого типу - осиковоберезові колки. Це динамічні рослинні асоціації, що переносять нестабільний водний

(C) І. М. Лоза, В. В. Бригадиренко, 2007

Вісник Дніпропетровського університету. Біологія, екологія.

Vìsnik Dnìpropetrovs'kogo unìversitetu. Serìa Bìologiâ, ekologîâ Visnyk of Dnipropetrovsk University. Biology, ecology. Vìsn. Dnìpropetr. Unìv. Ser. Bìol. Ekol. 2007. 15(1).

ISSN 2310-0842 print ISSN 2312-301X online www.ecology.dp.ua 
режим. Навесні на дні колків спостерігається присутність води, що зібралась у результаті танення снігу. Звичайно вода висихає до середини літа. Проходячи крізь піщаний грунт, вода виносить на глибину розчинені органічні сполуки. У результаті грунт профарбовується у буруватий колір і набуває слабкокислої реакції. На дні, у найбільш зволоженому місці, утворюється осокове болото або волога лука з гігро- та мезофітами.

При більш глибокому заляганні грунтових вод утворюються умови для зростання молодняків берези та осини. Самозасівні сходи розташовані “латками” різної площі. Часто після енергійного росту та досягнення висоти близько 2 м молодняк відмирає. Причина цього - мінливий водний режим. За нашими даними [9], глибина проникнення органічної речовини по профілю найбільша на дні колка. Вище по “стінах" колка гумусований горизонт різко скорочується (15-20 см завтовшки); у верхній частині він досягає лише декількох сантиметрів. У застійних умовах дна колка відбувається консервація органічної речовини та утворюється торфоподібний горизонт. В умовах арени результатом грунтотвірного процесу є грунти дерено-борового та дерено-болотного ряду автоморфного та гідроморфного (за наявності прісних грунтових вод) типів грунтоутворення. Осиково-березові колки важливі як асоціації, що зростають там, де інші форми деревних біогеоценозів не можуть існувати. Сформовані грунтові комбінації розмежовуються за ступенем еродованості рельєфу.

До першої групи входять грунти, що формуються на потужних пісках із промивним типом водного режиму та домінуванням окисних умов. Тут переважають аеробні процеси. Грунтовий профіль безструктурний пухкий, у сухому стані сипкий. Гумусований шар має невелику потужність, різко переходить у материнську породу - пісок.

Для другої групи грунтів у нижній частині профілю навесні характерне тимчасове перезволоження із короткочасним переважанням відновних процесів і наступною зміною їх окисними. Подібний тип грунтоутворення характерний для улоговин із глибиною залягання грунтових вод близько 3 м від поверхні.

Грунти третьої групи мають у більшості випадків надлишкове зволоження та випітний тип водного режиму протягом усього вегетаційного періоду. Тут переважають анаеробні процеси. Зміна відновного процесу на окисний відбувається в літньо-осінній період тільки у верхній частині профілю. По профілю грунту присутні сірі, сизо-бурі плями, що свідчать про процес оглеєння. Такий тип грунтоутворення притаманний грунтам осиково-березових колків із високим рівнем стояння грунтових вод. У вологі роки капілярна кайма підходить майже до поверхні. Нестабільний гідрологічний режим призводить до формування грунтів із диференційованим за елювіально-ілювіальним типом профілем.

Екологічна характеристика рослинності та трунтів колків свіжуватого типу місиезростання. Оточення - дубо-сосняк із сухуватим різнотрав'ям типу $B_{1}$. Діаметр колка - 70 м. Перша третина - найнижча позиція - центральна лука, вкрита мезофітами та мезогігрофітами. Проективне покриття - 10-15\%. Із трав'янистих рослин переважають Carex contigua L., Polygonum amphibium L., Tanacetum vulgare L. Друга третина - "кільце" з берези та осики. Проективне покриття травостою - 1-3\% (одиничні екземпляри Convallaria majalis L. та Geum urbanum L.).

Морфологічна характеристика грунтового профілю:
$H_{0} \quad 0-2 \mathrm{~cm}$
$H_{p} \quad 2-10 \mathrm{~cm}$
напіврозкладена підстилка з листя берези та осики;
$\begin{array}{ll}P_{h} & 10-40 \mathrm{~cm}\end{array}$ пухкопіщаний, свіжуватий горизонт, насичений корінням деревних порід;
$\begin{array}{lll}P_{1} & 40-50 \mathrm{~cm} & \text { поступовий; } \\ P_{2} & 50-100 \text { см } & \text { пухкопіщаний, вологий горизонт, із вк } \\ & \text { додмитий пісок білого кольору. }\end{array}$ пухкопіщаний, безструктурний, свіжуватий горизонт, світло-сірий, перехід поступовий;

Вісник Дніпропетровського університету. Біологія, екологія. Vìsnik Dnìpropetrovs'kogo unìversitetu. Serîa Bìologîa, ekologîâ Visnyk of Dnipropetrovsk University. Biology, ecology. Vìsn. Dnìpropetr. Unìv. Ser. Bìol. Ekol. 2007. 15(1).

ISSN 2310-0842 print ISSN 2312-301X online www.ecology.dp.ua 
Екологічна характеристика рослинності та трунтів колків вологих місиезростань. Осиково-березовий колок, розташований на межі заплави та арени. Діаметр 120 м. Перша третина колка (центр) - галявина шириною 20 м. Проективне покриття трав'яного ярусу - 30 \%: Pteridium aquilinum L., Rubus caesius L., Urtica dioica L., Aegopodium podagraria L., Geum urbanum L. У південно-східній частині колка, на схилі, що краще прогрівається та освітлюється, зростають Convallaria majalis L., Pteridium aquilinum L., Tanacetum vulgare L. Деревостан другої третини колка має наступну характеристику. Перший ярус: Betula pendula Rorh., Populus tremula L., одиничні екземпляри Pyrus communis L. Другий ярус: Acer campestre L., Tilia cordata L., Ulmus caprinifolia Rupp., Acer tataricum L., Corylus avellana L. У травостої - Stellaria graminea L., Convallaria majalis L., Pteridium aquilinum L., Viola mirabilis L. Проективне покриття - близько $2 \%$. Потужний шар опаду (у середньому 4 см товщиною), складений листям деревних порід.

Морфологічна характеристика грунтового профілю:

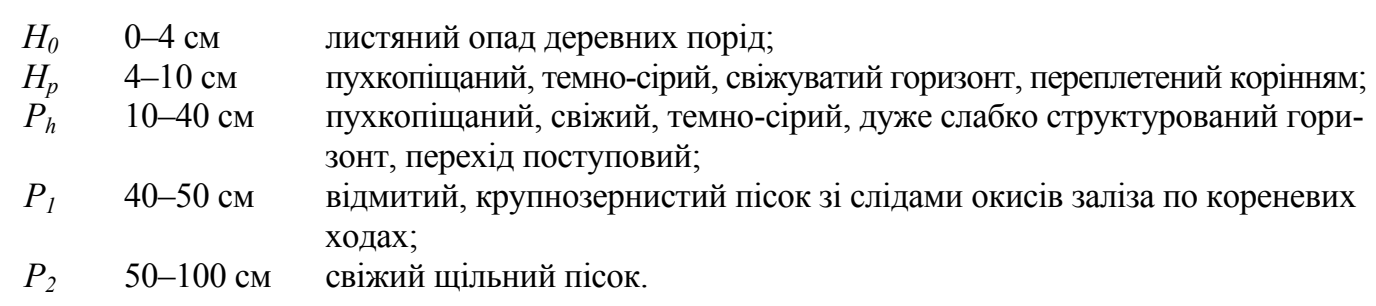

Грунт колка слід вважати дерено-лучним. Гумусований горизонт малопотужний (близько 30 см), генетичні горизонти виражені слабко, грунт безструктурний.

Характерна для осикових колків невисока мінералізація грунтових вод (30200 мг/л, на відміну від засолення грунтового розчину, у багатьох заплавних типах лісу до 500-2500 мг/л) є однією з головних причин формування специфічних епігейних фауністичних комплексів. Інший фактор формування герпетобію - значні сезонні та добові коливання мікрокліматичних умов, не властиві для більшості інших типів степових лісів $[1 ; 2 ; 7 ; 8]$. Під час моніторингових досліджень до пасток Барбера потрапляють переважно еврибіонтні та лісові види, не характерні для певного типу лісу (табл.). Значно збільшується (до 72 видів) перелік безхребетних при використанні інших методів збору, особливо на зволожених ділянках колків. Сезонна динаміка герпетобію у дощові весняний і осінній періоди виявляється у значній льотній міграції безхребетних із цих ділянок (чисельність більшості видів зменшується на порядок). Подібні явища спостерігаються частково й улітку, переважно під час червневих злив.

Таблиия

Чисельність турунів (Coleoptera, Carabidae) різних варіантів осикових фітоценозів арени р. Самара (особин / 10 пастко-діб)

\begin{tabular}{|l|c|c|c|c|}
\hline \multicolumn{1}{|c|}{$\begin{array}{c}\text { Вид турунів / } \\
\text { Характеристика герпетобію }\end{array}$} & $\begin{array}{c}\text { Осиковий } \\
\text { дубняк } \\
\text { із яглицею }\end{array}$ & $\begin{array}{c}\text { Осичник } \\
\text { із липою та } \\
\text { розхідником }\end{array}$ & $\begin{array}{c}\text { Осиково- } \\
\text { березовий } \\
\text { колок із } \\
\text { тонконогом }\end{array}$ & $\begin{array}{c}\text { Осиково- } \\
\text { березовий } \\
\text { колок із } \\
\text { очеретом }\end{array}$ \\
\hline 1 & 2 & 3 & 4 & 5 \\
\hline Carabus granulatus Linnaeus, 1758 & - & 0,058 & - & - \\
\hline C. marginalis Fabricius, 1794 & - & 0,167 & - & 0,019 \\
\hline Notiophilus laticollis Chaudoir, 1850 & - & - & - & 0,019 \\
\hline Bembidion biguttatum (Fabricius, 1779) & - & - & - & 0,043 \\
\hline Pterostichus ovoideus (Sturm, 1824) & - & 0,035 & - & - \\
\hline P. oblongopunctatus (Fabricius, 1787) & - & 0,093 & - & 0,037 \\
\hline P. niger (Schaller, 1783) & 0,227 & 0,023 & - & 0,015 \\
\hline P. melanarius (Illiger, 1798) & 0,035 & - & - & - \\
\hline
\end{tabular}

Вісник Дніпропетровського університету. Біологія, екологія.

Vìsnik Dnìpropetrovs'kogo unìversitetu. Serìâ Bìologîâ, ekologîâ Visnyk of Dnipropetrovsk University. Biology, ecology. Vìsn. Dnìpropetr. Unìv. Ser. Bìol. Ekol. 2007. 15(1).

ISSN 2310-0842 print ISSN 2312-301X online www.ecology.dp.ua 
Закінчення табл.

\begin{tabular}{|l|c|c|c|c|}
\hline \multicolumn{1}{|c|}{1} & 2 & 3 & 4 & 5 \\
\hline Amara aenea (De Geer, 1774) & - & - & - & 0,019 \\
\hline A. communis (Panzer, 1797) & - & - & - & 0,017 \\
\hline A. similata (Gyllenhal, 1810) & - & 0,019 & - & - \\
\hline Harpalus rufipes (De Geer, 1774) & 0,035 & 0,019 & 0,036 & 0,019 \\
\hline H. latus (Linnaeus, 1758) & - & 0,023 & - & 0,019 \\
\hline Badister lacertosus Sturm, 1815 & - & 0,019 & - & - \\
\hline Licinus depressus (Paykull, 1790) & 0,019 & 0,023 & - & - \\
\hline Panagaeus bipustulatus (Fabricius, 1775) & - & - & - & 0,052 \\
\hline P. cruxтаjor (Linnaeus, 1758) & - & 0,076 & - & - \\
\hline Сумарна чисельність Carabidae & 0,316 & 0,555 & 0,036 & 0,257 \\
\hline Кількість видів турунів & 4 & 12 & 1 & 11 \\
\hline
\end{tabular}

Осиково-березові колки - свосрідні рефугіуми, на території яких більшість лісових видів безхребетних переживає тривалу літню посуху. У цей період у різних стаціях колків формуються специфічні трофічні ланцюги, не характерні для інших типів лісу. "Місцева" фауна примушена конкурувати 3 великою кількістю неспецифічних для даних умов видів. Тому серед характерних для цих типів лісу видів переважають рідкісні гігрофільні та мезогігрофільні види (Badister dorsiger (Duftschmid, 1812), B. sodalis (Duftschmid, 1812) та ін.); специфічні мезофільні види відсутні.

\section{Висновки}

В умовах улоговин арен степових річок формуються осиково-березові колки рослинні асоціації, що пристосовані до існування на піщаних грунтах із нестабільним водним режимом. У цих умовах домінують рослини-сильванти (Viola mirabilis L., Convallaria majalis L., Anthriscus sylvestris (L.) Hoffm.). Герпетобій осиково-березових біогеоценозів арени ріки Самари являє собою бореально-неморальний фауністичний комплекс. Окрім евритопних лісових видів тут також поширені рідкісні гігрофільні та мезогігрофільні види, що збереглися на території степової зони лише в даному типі лісових екосистем.

\section{Бібліографічні посилання}

1. Апостолов Л. Г. Вредная энтомофауна лесных биогеоценозов Центрального Приднепровья. - К: Вища школа, 1981. - 232 с.

2. Апостолов Л. Г. Биотопическое распределение муравьев в лесах Присамарья / Л. Г. Апостолов, В. Е. Лиховидов // Вопросы степного лесоведения и охраны природы. Д.: ДГУ, 1976. - Вып. 6. - С. 139-145.

3. Белова Н. А. Естественные леса и степные почвы / Н. А. Белова, А. П. Травлеев. - Д.: ДГУ, 1999. - $348 \mathrm{c.}$

4. Бельгард А. Л. Лесная растительность юго-востока УССР. - К.: КГУ, 1950. - 263 с.

5. Бельгард А. Л. Степное лесоведение. - М.: Лесная промышленность, 1971. -336 с.

6. Высоцкий Г. Н. О боровых типах Чугуево-Бобчанского лесничества вблизи Харькова. Очерки по фитосоциологии и фитогеографии. - Л., 1929. - 138 с.

7. Грицан Ю. И. Экокриогенный аспект педоклимата степних эдафотопов // Вісник Дніпропетровського університету. Біологія. Екологія. - 2002. - Вип. 10, т. 1. - С. 10-18.

8. Кришталь О. П. Ентомофауна грунту та підстилки в долині середньої течії р. Дніпро. К.: КДУ, 1956. $-423 \mathrm{c}$.

9. Лоза И. М. Развитие идей А. Л. Бельгарда об экологических особенностях колковых биогеоценозов в степи // Екологія та ноосферологія. - 1999. - Т. 6, № 1-2. - С. 63-69.

10. Сукачев В.Н. Методические указания к изучению типов леса / В.Н. Сукачев, С. В. Зонн. - М., 1961. - 104 c.

Надійшла до редколегії 12.11.2006

90

Вісник Дніпропетровського університету. Біологія, екологія.

Vìsnik Dnìpropetrovs'kogo unìversitetu. Seriâ Bìologîa, ekologiâ

Visnyk of Dnipropetrovsk University. Biology, ecology. Vìsn. Dnìpropetr. Unìv. Ser. Bìol. Ekol. 2007. 15(1).

ISSN 2310-0842 print ISSN 2312-301X online www.ecology.dp.ua 